\title{
Major Factors Influencing the Performance of Local Private Third Party Logistics Service Providers in Southern China
}

\author{
Poon, Wai Kuen \\ International Graduate School of Business \\ University of South Australia \\ Adelaide SA, Australia \\ E-mail: irenewkp@yahoo.com \\ Canon Tong \\ International Graduate School of Business \\ University of South Australia \\ Adelaide SA, Australia \\ E-mail: canon.tong@unisa.edu.au
}

Received: December 4, 2011 Accepted: December 28, 2011 Published: January 1, 2012

doi:10.5296/jmr.v4i1.1140ＵRL: http://dx.doi.org/10.5296/jmr.v4i1.1140

\begin{abstract}
The increase in foreign trade resulting from China's membership of the World Trade Organization (WTO) created substantial pressure on its logistics system and made change inevitable for local private third party logistics service providers (3PLs) in China who found themselves unable to compete with the global logistics players who began operating in China after it joined the WTO. This study provides an empirically-based model to help local private 3PLs formulate appropriate strategies for improving their performance. Although there is a plethora of literature relating to the improvement of organizational performance and the development of quality management models, most of the studies have been conducted in Western countries and used only one or two organizational performance variables. This study sought to redress that by conducting a study of local 3PLs in southern China to empirically investigate the relationship between the four performance variables of the Balanced
\end{abstract}




\section{Macrothink

Scorecard and the six quality management factors developed for the Malcolm Baldrige National Quality Award. Although it was found that the six factors have a strong relationship with the four organizational performance variables, not all factors are significant constructs to each performance variable. The findings provide local private 3PLs in China with indicators as to which factors do and which factors do not have a positive and significant effect on each of the four organizational performance variables considered. The study clearly shows that performance improvement should not be considered from the financial perspective alone, but should also include customer orientation, business process, and learning and growth.

Keywords: Organizational performance, Balanced Scorecard, Quality management, Malcolm Baldrige National Quality Award, Third party logistics service providers, China 


\section{Introduction}

Previous studies relating to organizational performance improvement and quality management focused mainly on Western countries (Fotopoulos and Psomas, 2010; Kumar, Choisne, Grosbois and Kumar, 2009; Demirbag, Tatoglu, Tekinkus and Zaim, 2006; Lin, Chow, Madu, Kuei and Yu, 2005; Kuei, Madu and Lin, 2001) and used only one or two organizational performance variables (Hung, Lien, Yang, Wu and Kuo, 2010; Sit, Ooi, Lin and Chong, 2009; Jacob, Madu and Tang, 2004; Brah, Wong and Rao, 2000). This is the first study to investigate the relationship between the four organisational performance variables of the Balance Scorecard (BS) and the six quality management factors adapted from the Baldrige National Quality Award (MBNQA) in order to identify ways in which local private third-party logistics providers (3PLs) in southern China can compete more effectively with the international 3PLs that have been operating in China since it joined the WTO. The four performance perspectives proposed by the BS are financial, customer, business process, and learning and growth, while the MBNQA's six quality management factors are leadership, strategic planning, customer focus, analysis and measurement, human resource focus, and process management. The study produced a performance improvement model for local private logistics service providers in southern China that may be generalized to other areas of China and possibly to other counties.

\section{Literature Review}

\subsection{Organizational Performance}

This section explains the importance of performance measurement to companies. Organizational performance is the measurement of a firm's ability to compete and generate profits (Lok, Hung, Walsh, Wang and Crawford, 2005). It also measures and reflects the productivity, cost, market share, return on assets and profitability of an organization (Andersen, 2000). However, organizational performance is not just financial performance (Skerlavaj, Stemberger, Skrinjar and Dimovski, 2007) as the performance of an organization can also be evaluated from the perspectives of business performance and organization effectiveness (Venkatraman and Ramanujam, 1986).

Performance measures are used to check the financial and non-financial health of a business on a regular basis by financial and operating reports (Neely, 1998). Many organizations still rely on traditional financial performance measures but an over reliance on return on investment can distort strategy building and may conflict with strategic objectives (Tangen, 2004). According to Niven (2002), financial measures are not sufficient for measuring the performance of organizations for several reasons: inadequate value assessment of intangibles; little predictive power; financial performance maximization at the expense of cross-functional performance; and lack of direct relevance to personal prospects. Additionally, as pointed out by Hayes and Abernathy (1980), financial measures look for short term earnings at the expense of long term thinking.

Various systems have been developed by scholars and practitioners to give a complete picture of the performance of an organization. There are some prominent performance measurement 
systems such as the Performance Measurement Matrix (Keegan, Eiler and Jones, 1989), the SMART Pyramid (Lynch and Cross, 1991), the Result and Determinants Framework (Fitzgerald, Johnston, Brignall, Silvestro and Voss, 1991), the Macro Process Model (Brown, 1996), the Performance Prism (Kennerley and Neely, 2000), and the Balanced Scorecard (Kaplan and Norton, 1992). Some models were developed to address the problem of balancing measures and so include non-financial measures, such as operational results and customer satisfaction, as well as financial measures. However, they do not tackle the problem of dynamic adaptability as they are static and unable to respond to changing internal and external environments. Some other models are meant to solve the problem of process orientation but do not give due regard to stakeholder satisfaction (Garengo, Biazzo and Bititci, 2005).

\subsection{Balanced Scorecard}

Balanced scorecard has been commonly utilized by organization in their performance measurement. The Balanced Scorecard (BS) proposes that a company use a balanced set of causally-linked organizational performance measures to take a comprehensive view of the business from four perspectives: financial perspective, customer perspective, business process perspective, and learning and growth perspective. For each of the perspectives, there are objectives, measures, and targets (Kaplan and Norton, 1992). Successive modifications, in 1996, 2001, and 2004, improved the BS making it the performance measure of choice not only for the practical evaluation of organizations but also for research (Walsh, Lok and Jones, 2006). A survey covering five continents showed that around $62 \%$ of respondents have used the BS (Hendricks, Menor and Wiedman, 2004). It is an effective performance measurement and communication tool (Berkman, 2002; Gumbus and Lyons, 2002; Latshaw and Choi, 2002) that can help organizations strategically align their business and operational activities (Olve, Petri, Roy and Roy, 2004). Kaplan and Norton (2005) observed that the BS complements financial measures with operational measures of customer satisfaction, business processes, and innovative activities that create value for customers and ultimately increase revenue. The following elaborates on each one of the BS performance measures.

Financial perspective considers profitability and shareholder value. Measures such as return on investment and economic value-added can be improved by increasing sales revenue, decreasing operating costs, enhancing asset utilization (Walsh et al., 2006), and improving customer satisfaction and higher operating efficiency (Bourne, Franco and Wilkes, 2003).

Customer perspective focuses on providing value for the customer in the areas of price, quality, availability, service, partnership, and reputation in order to support the core outcomes of customer satisfaction, customer retention, and customer acquisition (Kaplan and Norton, 1996).

Business process perspective considers the reduction of waste, process efficiency, cost efficiency, and enhancement of company profitability, which leads to improved productivity and supports customer value propositions. 
Learning and growth perspective involves a company's ability to innovate, improve and learn, which is linked directly to its value (Kaplan and Norton, 2005) and competitive advantage (Day, 1994a; 1994b; Sinkula, 1994; Glazer, 1991); strong internal human, information and organizational capabilities are the ingredients of learning and growth (Walsh et al., 2006).

\subsection{Quality Management}

Quality management is vital to organizations. Quality management leads to organizational performance improvement (Douglas and Judge, 2001; Hendricks and Singhal, 1997); it is an essential way to improve the effectiveness and flexibility of an organization (Oakland, 1993). Nowadays, quality management is widely adopted in service industries (Millen and Maggard, 1997) and scholars generally agree that quality management can achieve better operational results and higher customer satisfaction (Lai, Lau and Cheng, 2004; Holcomb, 1994; Mentzer, 1993; Langley and Holcomb, 1992). There are various quality management tools such as ISO Standards, Six Sigma, the European Foundation for Quality Management model (EFQM), and the Malcolm Baldrige National Quality Award (MBNQA). The common objective of all these tools is to improve organizational performance by the provision of specific guidelines that support and lead an organization up the ladder of success (Van Der Wiele, Brown, Millen and Whelan, 2000).

\subsection{Malcolm Baldrige National Quality Award (MBNQA)}

MBNQA has been widely recognized for its contribution to the improvement of organizational performance. This prestigious quality award was established in the USA in 1987 and is presented in recognition of excellent performance as judged against six quality management critera: leadership; strategic planning; customer focus; measurement, analysis and knowledge management; human resource management; and process management (Jacob et al., 2004; NIST, 2002). Many organizations use the MBNQA criteria to improve their overall performance (US General Accounting Office, 1991), achieve business excellence (Bemowski and Stratton, 1995), and be more competitive in the marketplace (Knotts, Parrish and Evans, 1993). The criteria can also be used to predict future profitability (Ruben, Russ, Smulowitz and Connaughton, 2007) and to help with organizational change (Ruben, 2004). Each one of the criteria (hereinafter referred to as factors) is explained below.

Leadership not only helps an organization to improve operationally (Samson and Terziovski, 1999) but also increases customer satisfaction (Wilson and Collier, 2000). It has been found that leadership plays a greater role in small organizations where leadership also has a substantial effect on financial performance (Koene, Vogelaar and Soeters, 2002; Avolio, Waldman and Einstein, 1988). Leadership can also drive other quality management factors, such as strategic planning, human resource management, process management, and measurement and analysis to improve financial performance (Fotopoulos and Psomas, 2010; Wilson and Collier, 2000).

Strategic planning has a positive relationship with organizational performance (Miller and Cardinal, 1994; Sapp and Seiler, 1981; Wood and LaForge, 1979), particularly in dynamic and complex industries, and can enhance economic performance and organizational 
innovation (Andersen, 2000). However, Whitehead and Gupp (1985) claimed that strategic planning does not have an effect on performance.

Customer focus has a positive impact on organizational performance (Chong and Rundus, 2004; Nilsson, Johnson and Gustafsson, 2001; Ittner and Larcker, 1996; Anderson, Rungtusanatham and Schroeder, 1994). It may also directly affect the financial performance of a firm through market expansion, increasing market share (Zeithaml, Parasuraman and Berry, 1993; Fornell, 1992) and improving profitability (Kumar et al., 2009).

Measurement, analysis and knowledge management emphasises the importance of knowledge management and the management of information technology and systems. Definitions of knowledge management (KM) and organizational performance (Beckman, 1999; Bassi, 1997) concur that KM drives organizations to be more effective and competitive. Information technology helps organizations capture and distribute explicit knowledge (Cohen, 1998) that can be used to maintain customer focus and improve organizational performance (NIST, 1995). Particularly in the logistics service industry, IT is a critical factor for 3PL performance since logistics providers need to integrate systems with their clients (Vaidyanathan, 2005).

Human resource management has a significant effect on organizational performance (Ahmad and Schroeder, 2003; Samson and Terziovski, 1999; Delaney and Huselid, 1996) and can enhance competitive advantage (Wright, McMahan and McWilliams, 1994). Human resource may be particularly important in the logistics service industry because employees usually have direct contact with customers (Sit et al., 2009; Bartel, 2004). Some literature claims that employee satisfaction and staff turnover rate influences customer satisfaction (Voss, Tsikriktsis, Funk, Yarrow and Owen, 2004; Heskett, Jones, Loveman, Sasser and Schlesinger, 1994) and operation efficiency (Bourne et al., 2003), which in turn affects financial performance (Rucci, Kirn and Quinn, 1998) and overall organizational performance (Madu, Kuei and Jacob, 1996).

Process management aims to improve process efficiency (Montes, Jover and Fernandez, 2003) and operational effectiveness (Lok et al., 2005). It also influences organizational performance (Harmon, 2003; Kuei, Madu, Lin and Chow, 2002; Burlton, 2001; McCormack and Johnson, 2000), including lower operating cost, improved customer satisfaction (Kumar, Smart, Maddern and Maull, 2008; Maddern, Maull and Smart, 2007; Tsikriktsis and Heineke, 2004) and financial results (Reed, Lemak and Montgomery, 1996).

The foregoing review of the literature reveals that the four organisation performance measures of the BS and the six MBNQA quality management factors have a bearing on organizational performance either directly or indirectly. It also establishes the major concepts of the research framework and hypotheses for this study of local private 3PLs in southern China.

\section{Research Framework}

The framework adopts the six operation/quality management criteria (factors) developed for the MBNQA (NIST, 1987) as the independent variables, and the four organizational performance perspectives proposed by the BS as the dependent variables (Kaplan and Norton, 
1992). See Figure 1 below.

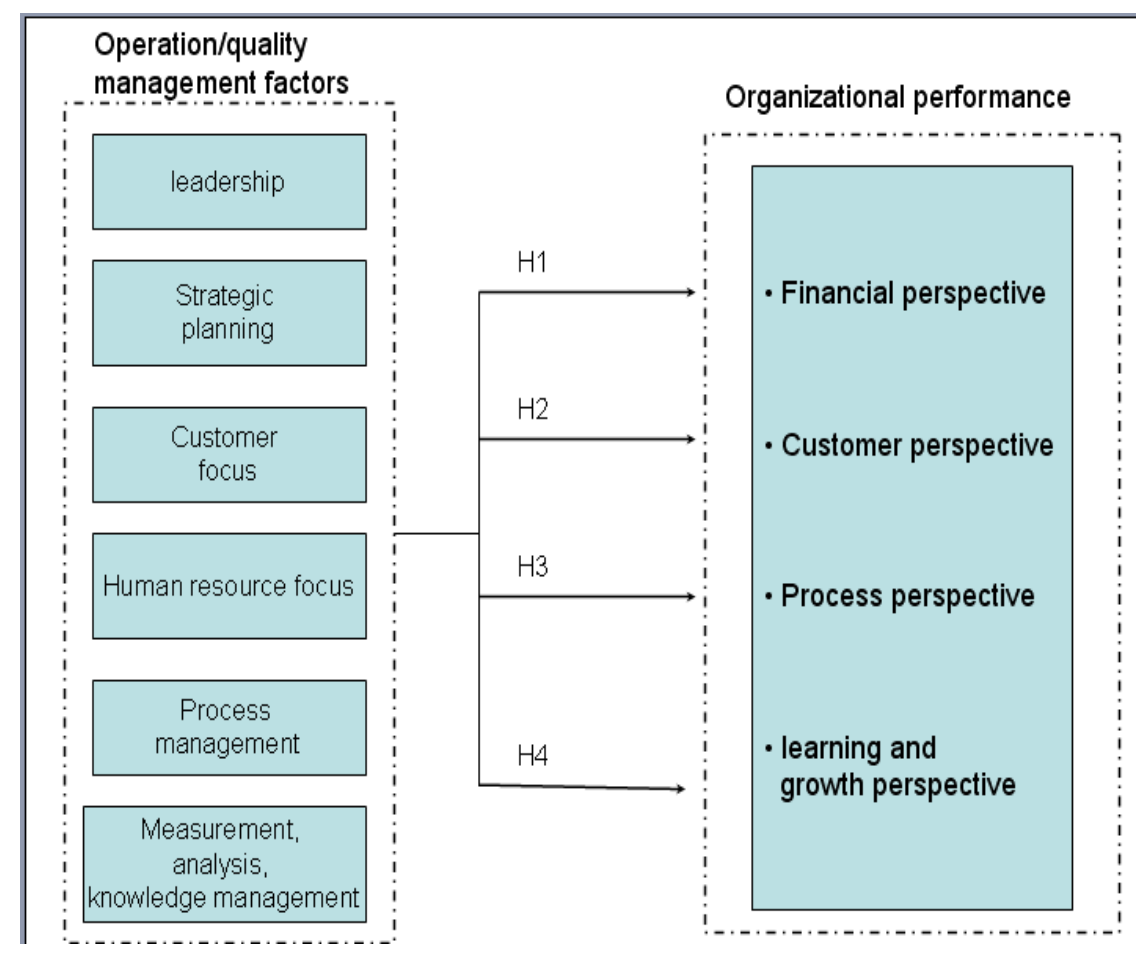

Figure 1. Research Framework

To explore the causal relationships between the six quality management factors and the four organizational performance perspectives, four hypotheses were developed. The following section identifies the hypotheses and provides a justification for each.

\subsection{Research Hypotheses}

Hypothesis 1: The six quality management factors have a positive effect on the financial performance of local private logistics service providers in southern China.

Justification - Financial performance was measured by combining return on investment, return on sales, revenue growth, and market share (Sale and Inman, 2003). Many researchers claim that quality management factors influence company productivity and financial results (Fotopoulos and Psomas, 2010; Kumar et al., 2009; Sila and Ebrahimpour, 2005; Kaynak, 2003) although some disagree (Powell, 1995; Adam, 1994).

Hypothesis 2: The six quality management factors have a positive effect on customer satisfaction of local private logistics service providers in southern China.

Justification - The generic outcome measures include customer satisfaction, customer retention, new customer acquisition, and market share (Kaplan and Norton, 1996). Many researchers claim that quality management factors influence customer satisfaction levels (Siddiqui and Rahman, 2007; Yang, 2006; Lin et al., 2005) and that customer focus may be the critical factor to increase customer satisfaction, competitive advantage and business profitability (Chong and Rundus, 2004; Crosby, 1996; Juran, 1992; Narver and Slater, 1990). 
Hypothesis 3: The six quality management factors have a positive effect on the business process performance of local private logistics service providers in southern China.

Justification - Process performance reflects the effectiveness, efficiency and costs of operational activities (Walsh et al., 2006; Anderson et al., 1998). Quality management has a positive correlation to operational performance of the organization (Hendricks and Singhal, 1997). According to Samson and Terziovski (1999), leadership, customer focus and human resource management are the most significant factors affecting operational performance.

Hypothesis 4: The six quality management factors have a positive effect on learning and growth performance of local private logistics service providers in southern China.

Justification - Organizational learning may be the most valuable dynamic capability (Teece, Pisano and Shuen, 1997) and learning can enhance organizational performance (Wageman, 1995). Organizations can enhance their competitive advantage through improving their learning ability (Skerlavaj et al., 2007; Zack, 2005; Bontis, Crossan and Hulland, 2002).

\subsection{Independent Variables: Quality Management Factors}

There are six quality management factors that help organizations to achieve planned organizational performance results. The framework adopts, as independent variables, these six quality management factors, comprising leadership (LS), strategic planning (SP), customer focus (CF), measurement, analysis, and knowledge management (MAKM), human resource focus (HRF), and process management (PM), developed by the MBNQA. Some questions from Lok et al. (2005) were also adopted and modified. The items in this part were measured using a Likert five-point scale with "1" being Strongly Disagree, "2" being Disagree, " 3 ” being Neutral, “4” being Agree, and "5” being Strongly Agree. It was designed to examine the level to which respondents agreed or disagreed with each of the following statements:

LS1= I know my organisation’s mission

LS2= My senior leaders use our organisation's values to guide us.

LS3 = My senior leaders create a work environment that helps me do my job.

LS4= My organization's leaders share information about the organization.

LS5= My senior leaders encourage learning that will help me advance in my career

LS6 $=$ My organization lets me know what it thinks is most important.

LS7= My organization asks what I think

SP1= As it plans for the future, my organization asks for my ideas.

SP2= I know the parts of my organization's plans that will affect me and my work.

SP3= We develop strategies based on customer needs.

SP4= Our core processes are an important input into our strategic plan. 
SP5= Our current strategic plan identifies the projects we actually undertake to improve our business processes.

SP6= Our strategic planning process encourages information sharing and cross functional cooperation.

CF1= I know who my most important customers are.

CF2= I keep in touch with my customers.

CF3= My customers tell me what they need and want.

CF4= I ask if my customers are satisfied or dissatisfied with my work.

$\mathrm{CF} 5=\mathrm{I}$ am allowed to make decisions to solve problems for my customers.

CF6= Our response time satisfies customers

CF7 $=$ We are interacting more with external customers.

MAKM1= I know how to measure the quality of my work.

MAKM2= I know how to analyze (review) the quality of my work to see if changes are needed.

MAKM3= I use these analyses for making decisions about my work.

MAKM4= I know how the measures I use in my work fit into the organization's improvement measures.

MAKM5= I get all the important information I need to do my work.

MAKM6= We have sufficient measures to permit a clear tracking of our performance.

HRF1= I can make changes that will improve my work.

HRF2 $=$ My boss encourages me to develop my job skills so I can advance in my career.

HRF3= My boss and my organization care about me.

HRF4= I have a safe workplace

HRF5= We are increasing the involvement in the way our work is planned.

HRF6= We are increasing our autonomy in making decisions that affect our work.

PM1= I collect information (data) about the quality of my work.

PM2= We have good processes for doing our work.

PM3= I have control over my work processes.

PM4= The number of employees involved in process improvement programmes increased in the last three years.

PM5= The number of process improvement projects has increased. 
PM6= Organization will definitely continue with process improvement programmes.

PM7= Our experience with process improvement programmes has generally been positive

\subsection{Dependent Variable: Organizational Performance}

The four organizational performance perspectives proposed by the BS, namely financial (FP), customer (CP), business process (PP), and learning and growth (LG), were adopted as the dependent variables. The questions generated by Lok et al. (2005) and Anderson et al. (1998) were used as part of the questionnaire in this research. Some questions from Kaplan and Norton $(1996,2001)$ were also adopted and modified. The items in this part were measured using a Likert-type five-point scale with " 1 " being Strongly Disagree and "5" being Strongly Agree. It was designed to examine the level to which respondents agreed or disagreed with the following items.

FP1= Our average cost per unit of product or service has decreased of the last two years.

FP2= Our overall sales revenue has growth over the last two years .

FP3= Our asset utilization has increased of the last two years.

FP4= Our sales revenue from existing customers has increased over the last two years.

FP5= Our organization's profitability has increased over the last two years.

FP6= Our sales revenue from new customers has increased over the last two years.

CP1= Customer satisfaction with our company's overall logistics performance increased over the last two years.

$\mathrm{CP} 2=$ Customer retention/loyalty has increased over the last two years.

$\mathrm{CP} 3=$ In depth relationship built between our organization and customers.

CP4= Our customer has high confidence in the capability of our organization to satisfy his/her requirements.

$\mathrm{CP} 5=$ Our organization attracts a number of new customers in established or new markets in the last two years

PP1= The quality of services has improved over the last two years

PP2= Logistics cost performance has improved over the last two years.

PP3= Effectiveness and efficiency of transaction processes has improved over the last two years

PP4= Order processing time has shortened over the last two years

PP5= Delivery performance has improved over the last two years

LG1 = The productivity of our employees has increased over the last two years.

LG2= Training investment per employment has increased over the last two years 
LG3= IT spend per employee has increased over the last two years.

LG4= Staff turnover has decreased over the last two years.

LG5= Absenteeism has decreased over the last two years.

\subsection{Research Methodology}

A quantitative cross-sectional web-based questionnaire survey was used to collect data for this research. The target participants were randomly selected managers of local private 3PLs in the southern Chinese provinces of Guangdong, Fujian and Guangxi. Simple random sampling was used to send 2,300 email invitations from which 294 responses were received. The response rate of $12.8 \%$ was considered satisfactory, since response rates for online surveys have been found to be between 4.4\% and 12.3\% (Daim and Kocaoglu, 2008; Sanders, 2007; Brounen, De Jong and Koedijk, 2006).

\subsubsection{Questionnaire}

The URL-hosted questionnaire comprised 74 closed-ended questions. The questions in Part A were designed to collect demographic information such as company age, ownership, asset value, job position of the respondent, number of full-time staff and their average education level, percentage of part-time staff and IT capabilities. Part B was designed to examine the importance of six quality management factors to local private logistics service companies. Part C examined organizational performance in four areas: financial, customer, business process, and learning and growth.

\subsubsection{Data Analysis}

Exploratory factor analysis (EFA) was conducted to analyze scores from a sample on independent and dependent variables, including quality management factors and organizational performance perspectives, to see if they could be reduced to underlying dimensions. If those variables are highly related to each other, they will load on one factor (Tharenou, Donohue and Cooper, 2007) and their loadings on the factor should be 0.40 or greater (Kim and Mueller, 1978). Items with a factor loading less than 0.4 need to be deleted (Hair, Black, Babin, Anderson and Tatham, 2006). Internal consistency reliability was examined by computing Cronbach's Alpha for each scale (Coakes, Steed and Price, 2008); while alpha coefficients of 0.70 and above are required of established scales (Nunnally and Bernstein, 1994; Fornell and Larcker, 1981), internal consistency coefficients of 0.60 or better are acceptable for a newly developed scale (Nunnally, 1978). As all measures in the questionnaire were developed from validated research in published journals, it was assumed that the content validity and construct validity of each measurement in the questionnaire should be reasonably high. Pearson correlation coefficient was used to test the positive effect of the six quality management factors on each of the four organizational performance perspectives. Correlation matrices indicate the direction and strength of the relationship between each quality management factor and the four organizational performance variables. Regression analysis was used to determine if the independent variables (quality management factors) correlated with the dependent variables (organizational performance perspectives). 


\section{Macrothink}

\section{Results}

Two hundred ninety four valid responses were received, from which the demographics details were extracted as shown in Table 1.

Table 1. Descriptive Statistics for Demographic Details

\begin{tabular}{|c|c|c|c|}
\hline \multicolumn{2}{|c|}{ Demographic details Measures } & \multirow{2}{*}{$\begin{array}{l}\text { Frequency } \\
68\end{array}$} & \multirow{2}{*}{$\frac{\text { Percentage }}{23.1}$} \\
\hline Designation & of Manager & & \\
\hline respondents & General Manager & 89 & 30.3 \\
\hline & Director & 80 & 27.2 \\
\hline & Vice President & 57 & 19.4 \\
\hline & Total & 294 & 100 \\
\hline \multirow[t]{5}{*}{ Type of ownership } & State Owned & 20 & 6.8 \\
\hline & $\begin{array}{l}\text { Chinese } \\
\text { private/local owned }\end{array}$ & 198 & 67.4 \\
\hline & Joint venture & 50 & 17 \\
\hline & Foreign Owned & 26 & 8.8 \\
\hline & Total & 294 & 100 \\
\hline \multirow[t]{4}{*}{$\begin{array}{l}\text { Years of operatiol } \\
\text { in China }\end{array}$} & on $<3$ yrs & 60 & 20.4 \\
\hline & $3-8$ yrs & 104 & 35.4 \\
\hline & $>8$ yrs & 130 & 44.2 \\
\hline & Total & 294 & 100 \\
\hline \multirow{9}{*}{$\begin{array}{l}\text { Types of } \\
\text { offered }\end{array}$} & ce Sea freight & 5 & 1.7 \\
\hline & Warehousing & 16 & 5.5 \\
\hline & Distribution & 38 & 12.9 \\
\hline & Integrated logistics & 215 & 73.2 \\
\hline & $\begin{array}{l}\text { Intermodal } \\
\text { transportation }\end{array}$ & 17 & 5.8 \\
\hline & land freight & 1 & 0.3 \\
\hline & Packing/repackaging & 1 & 0.3 \\
\hline & Consultation & 1 & 0.3 \\
\hline & Total & 294 & 100 \\
\hline
\end{tabular}


No. of full time staff $<100$

$$
100-499
$$

$500-999$

1000 or more

Total

of

\section{Percentage}

contract staff

$<=10 \%$
$>10 \%$ and $<20 \%$
$>20 \%$ and $<30 \%$
$>30 \%$ and $<40 \%$
$>40 \%$

Total

$$
\text { asset }<1
$$

60

20.4

value

$\begin{array}{lll}1-<10 & 134 & 45.6 \\ 10-<50 & 76 & 25.9 \\ 50 \text { or more } & 24 & 8.1 \\ \text { Total } & 294 & 100\end{array}$

Table 2. Education Level of Staff

\begin{tabular}{|l|l|l|l|l|l|l|}
\hline \multirow{2}{*}{$\begin{array}{l}\text { Education } \\
\text { Level }\end{array}$} & \multicolumn{2}{l|l|l|}{ Operational Staff } & \multicolumn{2}{l|}{ Middle Management } & \multicolumn{2}{l|}{ Senior Management } \\
\cline { 2 - 8 } & Frequency & Percent & Frequency & Percent & Frequency & Percent \\
\hline Primary & 132 & 44.9 & 0 & 0 & 0 & 0 \\
\hline Secondary & 61 & 20.7 & 50 & 17 & 0 & 0 \\
\hline Post-secondary & 101 & 34.4 & 236 & 80.3 & 62 & 21.1 \\
\hline Degree & 0 & 0 & 6 & 2.0 & 176 & 59.9 \\
\hline Postgraduate & 0 & 0 & 2 & 0.7 & 56 & 19.0 \\
\hline Total & 294 & 100 & 294 & 100 & 294 & 100 \\
\hline
\end{tabular}


Table 3. Use of Internet in Business Operations

\begin{tabular}{|l|l|l|l|l|l|l|l|l|}
\hline \multirow{2}{*}{ Response } & \multicolumn{2}{|l|}{ Have website } & \multicolumn{2}{l|}{ Online transaction } & \multicolumn{2}{l|}{$\begin{array}{l}\text { Online } \\
\text { system }\end{array}$} \\
\cline { 2 - 9 } & Frequency & Percent & Frequency & Percent & Frequency & Percent & Frequency & Percent \\
\hline Yes & 287 & 97.6 & 96 & 32.7 & 108 & 36.7 & 99 & 33.7 \\
\hline No & 7 & 2.4 & 198 & 67.3 & 186 & 63.3 & 195 & 66.3 \\
\hline Total & 294 & 100.0 & 294 & 100.0 & 294 & 100.0 & 294 & 100.0 \\
\hline
\end{tabular}

Results of the Kraiser-Meyer-Olkin (KMO) and Bartlett's Test on the quality management factors show that KMO value is 0.858 , meaning that the sampling adequacy is very good, meeting the assumption for EFA. Since the significant value for Bartlett's Test of Sphericity ( $p$ value) is 0.0001 , less than the significant level 0.05 as a rule of the thumb, therefore, there is no identity matrix in the inter-correlation of variables. Additionally, the sample size is found sufficient for conducting EFA ( $\mathrm{n} / \mathrm{k}$ is $294 / 2=147)$ as $\mathrm{n} / \mathrm{k}$ is greater than 5 . After three necessary assumptions met, EFA was carried out using the extracting method of principal component analysis (PCA) and rotation method of oblimin on items representing Leadership (LS), Strategic Planning (SP), Customer Focus (CF), Measurement, Analysis and Knowledge Management (MAKM), Human Resource Focus (HRF), and Process Management (PM).

Although the MBNQA (NIST, 1987) established seven non-mutually exclusive factors, in the current research context, there are only two factors because the items relating to LS, SP, CF and PM all appear under Component 1 while items relating to MAKM and HRF load under Component 2. Thus Component 1 has been labeled as Organizational Strength and Component 2 labeled as Individual Strength to reflect the strength of the individual items.

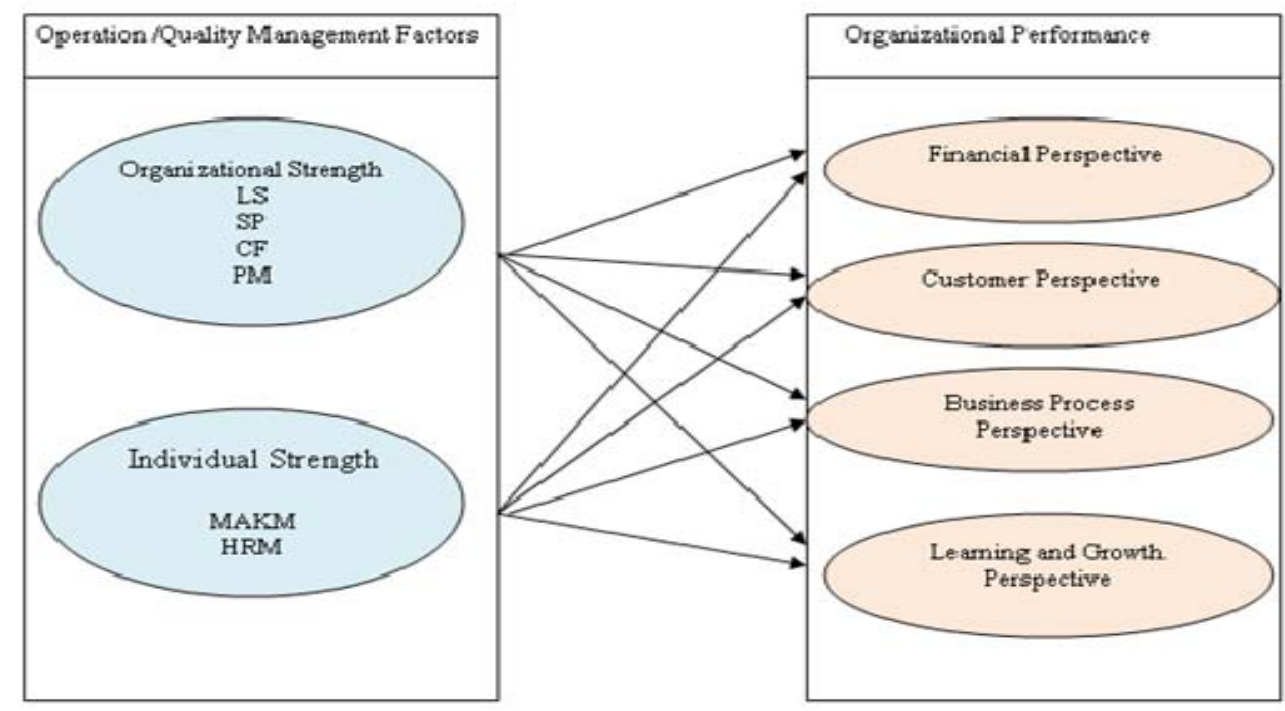

Figure 2. Factor Analysis for Quality Management Factors 
In KMO and Bartlett's Test on organizational performance, the result indicates that the KMO value is 0.6 , showing that the sampling adequacy is just adequate for this study and that it meets the assumption for EFA. Additionally, the $\mathrm{p}$ value is 0.0001 , less than 0.05 as a rule of thumb, and $\mathrm{n} / \mathrm{k}$ is greater than $5(\mathrm{n} / \mathrm{k}=147)$, meaning that the sample size was sufficient for conducting EFA, which was carried out using the extracting method of PCA and rotation method of oblimin on items representing Financial Perspective (FP), Customer Perspective (CP), Process Perspective (PP) and Learning and Growth (LG).

All Cronbach's alpha values for quality management constructs and organizational performance constructs exceed the minimum requirement set by Nunnally's (1978), which is at 0.6, and as the values are between 0.74 and 0.94 , the internal consistency are desirable (Shin, Collier and Wilson, 2000). Therefore, all quality management constructs and organizational performance constructs have been reliably measured and fulfill the requirement for convergent and discriminant validity.

\subsection{Hypothesis Testing}

Hypothesis H1:

All six quality management factors, Strategic Planning, Customer Focus, Measurement Analysis and Knowledge Management; Human Resource Focus, Process Management, and Leadership show significant and positive effects on the Financial Perspective of local private logistics service providers in southern China $(r=0.284$, $p$-value $=0.0001 ; r=0.156$, $p$-value $=0.014 ; \mathrm{r}=0.254$, $\mathrm{p}$-value $=0.0001 ; \mathrm{r}=0.533, \mathrm{p}$-value $=0.0001 ; \mathrm{r}=0.539$, $\mathrm{p}$-value $=0.0001$; $\mathrm{r}=0.180$, p-value $=0.006$ respectively). Hence, hypothesis $\mathrm{H} 1$ is supported.

Hypothesis H2:

Not all six quality management components have a positive effect on Customer Perspective. Measurement, Analysis and Knowledge Management (MAKM) has a significant and positive effect on customer satisfaction of local private logistics service providers in southern China ( $\mathrm{r}$ $=0.668$, p-value $=0.0001$ ). Similarly, Human Resource Focus has a significantly positive effect on customer satisfaction of Chinese private logistics service providers in southern China ( $r=0.604$, p-value $=0.0001)$. Whereas, Strategic Planning, Leadership, and Customer Focus have a significant but negative effect on customer satisfaction of local private logistics service providers in southern China $(\mathrm{r}=-0.158$, $\mathrm{p}$-value $=0.013 ; \mathrm{r}=-0.322$, $\mathrm{p}$-value $=$ $0.0001 ; \mathrm{r}=-0.196, \mathrm{p}$-value $=0.003$ respectively). Process Management's relationship on Customer Satisfaction of local private logistics service providers in southern China is not significant at the $5 \%$ level of significance. However, Process Management shows a significant negative effect on customer satisfaction at the $10 \%$ level of significance $(\mathrm{r}=$ 0.100 , p-value $=0.08$ ). Hence, hypothesis $\mathrm{H} 2$ is partially supported because it was shown that not each factor has a positive effect on customer performance.

Hypothesis H3:

In view of Process Perspective, Strategic planning, Customer Focus, Process Management, and Leadership indicate a significant and positive effect on the Process Perspective of 
Chinese private logistics service providers in southern China $(r=0.513$, $p$-value $=0.0001 ; r=$ $0.521, \mathrm{p}$-value $=0.0001 ; \mathrm{r}=0.510, \mathrm{p}$-value $=0.0001 ; \mathrm{r}=0.638, \mathrm{p}$-value $=0.0001$ respectively). Whereas, MAKM and HRF show significant but negative effect on Process Perspective of local private logistics service providers in southern China $(r=-0.160$, p-value $=0.012 ; \mathrm{r}=-0.185$, $\mathrm{p}$-value $=0.005$ ). Hence, hypothesis H3 is partially supported as only four factors have positive effect on the Process Perspective.

Hypothesis H4:

Amongst the six quality management factors Strategic Planning, Customer Focus, Human Resource Focus, Leadership, and Measurement Analysis and Knowledge Management show a significant negative effect on the Learning and Growth Perspective of local private logistics service providers in southern China (SP: $r=-0.25$, $\mathrm{p}$-value $=0.0001$; $\mathrm{CF}: \mathrm{r}=-0.279$, $\mathrm{p}$-value $=0.0001$; MAKM: $\mathrm{r}=-0.258$, $\mathrm{p}$-value $=0.0001$; HRF $\mathrm{r}=-0.162$, $\mathrm{p}$-value $=0.011 ; \mathrm{LS}: \mathrm{r}=-$ 0.308 , p-value $=0.0001$ ). Process Management, however, shows that its relationship with the Learning and Growth Perspective of local private logistics service providers in southern China is not significant (PM: $r=-0.032$, p-value $=0.328$ ). Hence, hypothesis $\mathrm{H} 4$ is rejected.

The following four tables (Table 4, Table 5, Table 6, Table 7) use coefficients to find which among the six quality management factors is the most important in financial, customer, process, and learning and growth performance.

Table 4. Coefficients of Quality Management Factors to Financial Performance

\begin{tabular}{|c|c|c|c|c|c|c|}
\hline \multirow[t]{2}{*}{ Model } & & \multicolumn{2}{|c|}{$\begin{array}{l}\text { Unstandardized } \\
\text { Coefficients }\end{array}$} & \multirow{2}{*}{ 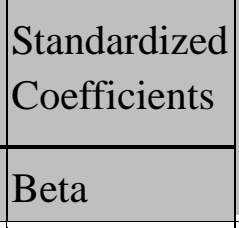 } & \multirow[t]{2}{*}{$\mathrm{t}$} & \multirow[t]{2}{*}{ Sig. } \\
\hline & & B & Std. Error & & & \\
\hline \multirow[t]{7}{*}{1} & (Constant) & 2.766 & .610 & & 4.531 & .0001 \\
\hline & SP & -.028 & .117 & -.026 & -.236 & .813 \\
\hline & $\mathrm{CF}$ & -.529 & .087 & -.547 & -6.092 & .0001 \\
\hline & MAKM & -.428 & .073 & -.459 & -5.901 & .0001 \\
\hline & HRF & .882 & .086 & .881 & 10.270 & .0001 \\
\hline & PM & .869 & .105 & .651 & 8.254 & .0001 \\
\hline & LS & .146 & .138 & .107 & 1.057 & .292 \\
\hline
\end{tabular}

a. Dependent Variable: Financial Perspective

The coefficient results show that CF, MAKM, HRF and PM are significant constructs to financial performance as their p-values are $<0.05$. According to Cohen (1992), if the Adjusted $\mathrm{R}^{2}$ is $>25 \%$, the relationship is strong. The result shows that the relationship between all quality management factors and financial performance is strong (Adjusted $\mathrm{R}^{2}=$ 0.619), which means that $61.9 \%$ of the financial perspective is explained. 
Table 5. Coefficients of Quality Management Factors to Customer Performance

\begin{tabular}{|c|c|c|c|c|c|c|}
\hline \multirow[t]{2}{*}{ Model } & & \multicolumn{2}{|c|}{$\begin{array}{l}\text { Unstandardized } \\
\text { Coefficients }\end{array}$} & \multirow{2}{*}{\begin{tabular}{|l|} 
Standardize \\
d \\
Coefficient \\
s \\
Beta
\end{tabular}} & \multirow[t]{2}{*}{$\mathrm{t}$} & \multirow[t]{2}{*}{ Sig. } \\
\hline & & B & Std. Error & & & \\
\hline \multirow[t]{7}{*}{1} & (Constant) & 7.685 & .530 & & 14.496 & .0001 \\
\hline & SP & -.145 & .102 & -.153 & -1.418 & .158 \\
\hline & $\mathrm{CF}$ & -.371 & .075 & -.436 & -4.915 & .0001 \\
\hline & MAKM & .400 & .063 & .488 & 6.358 & .0001 \\
\hline & HRF & .371 & .075 & .421 & 4.973 & .0001 \\
\hline & PM & -.068 & .091 & -.058 & -.741 & .460 \\
\hline & LS & .207 & .120 & .172 & 1.726 & .086 \\
\hline
\end{tabular}

Dependent Variable: Customer Perspective

The coefficient results show that CF, MAKM, HRF and LS are significant constructs to customer performance as their p-values are $<0.05$. Additionally, the relationship between these six factors and customer performance is strong as the adjusted $\mathrm{R}^{2}=0.629$, which means that $62.9 \%$ of the customer perspective is explained.

Table 6. Coefficients of Quality Management Factors to Process Performance

\begin{tabular}{|c|c|c|c|c|c|c|}
\hline \multirow[t]{2}{*}{ Model } & & \multicolumn{2}{|c|}{$\begin{array}{l}\text { Unstandardized } \\
\text { Coefficients }\end{array}$} & \multirow{2}{*}{$\begin{array}{l}\text { Standardize } \\
\text { d } \\
\text { Coefficients } \\
\text { Beta }\end{array}$} & \multirow[t]{2}{*}{$\mathrm{T}$} & \multirow[t]{2}{*}{ Sig. } \\
\hline & & B & Std. Error & & & \\
\hline \multirow[t]{7}{*}{1} & (Constant) & 5.184 & .514 & & 10.078 & .0001 \\
\hline & SP & -.085 & .099 & -.108 & -.857 & .392 \\
\hline & $\mathrm{CF}$ & .244 & .073 & .344 & 3.338 & .001 \\
\hline & MAKM & .068 & .061 & .099 & 1.113 & .267 \\
\hline & HRF & -.349 & .072 & -.474 & -4.816 & .0001 \\
\hline & PM & .316 & .089 & .322 & 3.560 & .0001 \\
\hline & LS & .244 & .117 & .243 & 2.093 & .038 \\
\hline
\end{tabular}

a. Dependent Variable: Process Perspective 


\section{Macrothink}

The results show that CF, HRF, PM and LS are significant constructs to process performance as their p-values are $<0.05$. The relationship between these six factors and process performance is strong (Adjusted $\mathrm{R}^{2}=0.499$ ), which means that $49.9 \%$ of the Process Perspective is explained.

Table 7. Coefficients of Quality Management Factors to Learning and Growth Performance

\begin{tabular}{|l|l|l|l|l|l|}
\hline \multirow{2}{*}{ Model } & \multicolumn{2}{|l|}{$\begin{array}{l}\text { Unstandardized } \\
\text { Coefficients }\end{array}$} & $\begin{array}{l}\text { Standardized } \\
\text { Coefficients }\end{array}$ & $\mathrm{t}$ & \multirow{2}{*}{ Sig. } \\
\cline { 2 - 5 } & $\mathrm{B}$ & Std. Error & Beta & & \\
\hline (Constant) & 8.849 & .752 & & 11.764 & .0001 \\
SP & .018 & .145 & .019 & .126 & .900 \\
CF & -.001 & .107 & -.001 & -.011 & .991 \\
MAKM & -.295 & .089 & -.349 & -3.305 & .001 \\
HRF & -.061 & .106 & -.067 & -.578 & .564 \\
PM & .770 & .130 & .636 & 5.939 & .0001 \\
LS & -.980 & .170 & -.790 & -5.749 & .0001 \\
\hline
\end{tabular}

Dependent Variable: Learning and Growth Perspective

The coefficient results show that MAKM, PM and LS are significant constructs to learning and growth performance as their p-values are $<0.05$. The relationship between these six factors and learning and growth performance is strong (Adjusted $\mathrm{R}^{2}=0.298$ ), means that 29.8 $\%$ of the Learning and Growth Perspective is explained. 
Table 8. Summary of Hypotheses Testing Results

Hypothesis

Result
Hypothesis The six quality management factors have a positive effect on H1 the financial performance of local private logistics service Supported providers in southern China.
Hypothesis The six quality management factors have a positive effect on
Hypothesis the customer performance of local private logistics service Partially providers in southern China.

The six quality management factors have a positive effect on
Hypothesis the business process performance of local private logistics

H3 service providers in southern China.

Hypothesis The six quality management factors have a positive effect on $\mathrm{H} 4$ service providers in southern China.

\section{Discussion}

The results show that all quality management factors have a strong relationship with the four performance variables but not all factors are significant constructs to each organizational performance variable. The result also demonstrate that all six factors have a positive effect on financial performance but a negative effect on the learning and growth performance variable. The findings show that organizational strength (SP, CF, PM and LS) is positively related to process performance and that individual strength (MAKM and HRF) has a positive effect on customer performance.

This study has several managerial implications for local private 3PLs in southern China. The results provide a useful indication to logistics management practitioners in China as to which quality management factors are significant for each of the performance variables, and also help local private 3PLs to understand how to improve their organizational performance.

The results demonstrate that leadership is a significant construct to three performance variables, including learning and growth performance $(\mathrm{t}=-5.749, \mathrm{p}$-value $=0.00005)$, customer performance $(\mathrm{t}=1.726$, $\mathrm{p}$-value $=0.043)$ and business process performance $(\mathrm{t}=$ 2.093, p-value $=0.019$ ).

The results further demonstrate that human resource is one of the significant constructs to customer service performance $(\mathrm{t}=4.973$, $\mathrm{p}$-value $=0.00005)$, and generates a positive effect on customer satisfaction. However, most 3PLs in China have concerns over shortages of qualified logistics personnel (Kam, Tsahuridu and Ding, 2010; Wang, Zantow, Lai and Wang, 
2006; Hong, Chin and Liu, 2004) so training is particularly important to companies with considerable amount of unskilled employees (Cooke, 2005). Employee attitudes affect customer satisfaction, particularly in the service industry, and the improvement of employee attitude increases customer satisfaction and revenue (Rucci et al., 1998). Local private 3PLs are therefore recommended to provide more training to improve the working attitude of their staff (Wang et al., 2006).

Human resource is a significant construct to process performance $(\mathrm{t}=-4.816$, $\mathrm{p}$-value $=$ 0.00005). Kaplan and Norton (2004) found that employees with the right skills, talent, and knowledge have a great impact on business process improvement, and Lieb and Bentz (2005) observed that 3PLs' success was related to the logistics talents. According to the research findings, human resource is also a significant construct to financial performance $(t=10.270$, p-value $=0.00005)$. Kaplan and Norton (1996) indicated that knowledgeable employees would improve sales effectiveness.

Interestingly, the research results indicate that the measurement, analysis, and knowledge management factor is not a significant construct to process performance $(\mathrm{t}=1.113, \mathrm{p}$-value $=$ 0.1335). Samson and Terziovski (1999) arrived at similar findings by showing that information and analysis did not have significant positive effect on organizational performance. This may be the case because many local private logistics service enterprises do not actively develop work measurement systems to assess the work performance and productivity of their employees; management may still rely on reward systems to enhance the working morale of operational and supervisory staff.

However, the knowledge management system is shown to be significant to learning and growth performance $(\mathrm{t}=-3.305$, $\mathrm{p}$-value $=0.0005)$ in the results. In knowledge-based economies, companies should use the skills and knowledge of their employees to sustain their competitive advantage (Burrows, Drummond and Martinsons, 2005). Development of a formal knowledge management system is necessary because it may increase knowledge transfer throughout the organization and improve employees' skills (Kaplan and Norton, 2004).

Although the results demonstrate that the measurement, analysis, and knowledge management factor is significant to customer performance $(\mathrm{t}=6.358$, $\mathrm{p}$-value $=0.00005)$, Anderson et al. (1998) revealed that work measurement systems would not directly affect customer satisfaction but may have an indirect effect on customer performance.

In conclusion, these findings provide management practitioners in southern China's local private 3PLs with some indication as to the factors that do and do not have a positive and significant effect on organizational performance variables. These findings suggest that local private 3PLs in southern China need to allocate more resources to performance variables if they hope to improve.

\subsection{Limitations of the Study and Future Research}

The cross-sectional design used for this study provided only a static snapshot of the phenomenon being studied and the quantitative methodology did not allow for understanding 
the reasons for the unusual relationship between six quality management factors and learning and growth performance, and why these factors have different significances to individual performance variables. Another limitation of the study was that informants who provided the data for analysis were from a single source only (managers of local 3PLs in southern China).

A combination of both qualitative and quantitative research using multiple informant sources is recommended for future studies of this nature. Using a case study approach to gather in-depth information on a single entity may remedy the limitations of a single source of data (Griffith and Lusch, 2007; Sandelowski, 2000), allow understanding of individual cases (Cavana, Delahaye and Sekaran, 2001), and help to explain the differences in the significance of quality management factors on organizational performance.

Further research could investigate why not all quality management factors are significant constructs to each of the performance variables in local private 3PLs in China. It is further recommended to explore other independent variables, moderating variables or intervening variables that may influence the four performance variables. A longitudinal study is recommended to review changes in the significance of quality management factors on the organizational performance of local private 3PLs over a period of time.

\section{References}

Adam, E. E. (1994). Alternative quality improvement practices and organization performance. Journal of Operations Management, 12, 27-44. http://dx.doi.org/10.1016/0272-6963

Ahmad, S., \& Schroeder, R. G. (2003). The impact of human resource management practices on operational performance: Recognizing country and industry differences. Journal of Operations Management, 21(1), 19-43. http://dx.doi.org/10.1016/S0272-6963

Andersen, T. J. (2000). Strategic planning, autonomous actions and corporate performance. Long Range Planning, 33, 184-200. http://dx.doi.org/10.1016/S0024-6301(00)00028-5

Anderson, J., Rungtusanatham, M., \& Schroeder, R. (1994). A theory of quality management underlying the Deming management method. Academy of Management Review, 19(3), 472-509. http://dx.doi.org/10.2307/258936

Anderson, R. D., Jerman, R. E., \& Crum, M. R. (1998). Quality management influences on Logistics performance. Logistics and Transportation Revision, 34(2), 137-148. http://dx.doi.org/10.1016/S1366-5545

Avolio, B. J., Waldman, D. A., \& Einstein, W. O. (1988). Transformational leadership in a management game simulation: Impacting the bottom line. Group and Organization Management, 13, 59-80. http://dx.doi.org/10.1177/105960118801300109

Bartel, A. P. (2004). Human resource management and organizational performance: Evidence from retail banking. Industrial and Labour Relations Review, 57(2), 181-203. http://dx.doi.org/10.2307/4126616

Bassi, L. J. (1997). Harnessing the power of intellectual capital. Training and Development, 51(2), 25-30. 
Beckman, T. J. (1999). The current state of knowledge management. In J. Lieb Table 3: Use of Internet in Business Operations. In J. Liebowitz (Eds.), Knowledge Management Handbook. Boca Raton: CRC Press.

Bemowski, K., \& Stratton, B. (1995). How do people use the Baldrige Award criteria? Quality Progress, 28(5), 43-47.

Berkman, E. (2002). How to use the Balanced Scorecard; you can't tell when you're winning if you don't keep score. The Balanced Scorecard helps track your hits and misses. CIO, 15(15), 1-4.

Bontis, N., Crossan, M., \& Hulland, J. (2002). Managing an organizational learning system by aligning stocks and flows. Journal of Management Studies, 39(4), 437-469. http://dx.doi.org/10.1111/1467-6486.t01-1-00299

Bourne, M., Franco, M., \& Wilkes, J. (2003). Corporate performance management. Measuring Business Excellence, 7(3), 15-21. http://dx.doi.org/10.1108/13683040310496462

Brah, S. A., Wong, J. L., \& Rao, B. M. (2000). TQM and business performance in the service sector: A Singapore study. International Journal of Operations and Production Management, 20(11), 1293-1312. http://dx.doi.org/10.1108/01443570010348262

Brounen, D., De Jong, A., \& Koedijk, K. (2006). Capital structure policies in Europe: Survey evidence. Journal of Banking and Finance, 30(5), 1409-1442. http://dx.doi.org/10.1016/j.jbankfin.2005.02.010

Brown, M. G. (1996). Keeping score: Using the right metrics to drive world-class performance. New York: Quality Resources.

Burlton, R. T. (2001). Business process management: Profiting from process. Indianapolis: Sams Publishing.

Burrows, G. R., Drummond, D. L., \& Martinsons, M. G. (2005). Knowledge management in China. Communications of the ACM, 48(4), 73-76. http://dx.doi.org/10.1145/1053291.1053322

Cavana, R. Y., Delahaye, B. L., \& Sekaran, U. (2001). Applied business research: Qualitative and quantitative methods. Milton, QLD: John Wiley \& Sons.

Chong, V. K., \& Rundus, M. J. (2004). Total quality management, market competition and organizational performance. The British Accounting Review, 36, 155-172. http://dx.doi.org/10.1016/j.bar.2003.10.006

Coakes, S. J., Steed, L., \& Price, J. (2008). SPSS version 15.0 for Windows: Analysis without anguish. Milton, QLD: John Wiley \& Sons.

Cohen, J. (1992). A power primer. Psychological Bulletin, 112(1), 155-159. http://dx.doi.org/10.1037/0033-2909.112.1.155

Cohen, D. (1998). Towards a knowledge context. California Management Review, 40(3), 
22-39.

Cooke, F. L. (2005). HRM, work and employment in China. London: Routledge.

Crosby, P. (1996). Quality is free: Making quality certain in uncertain times. New York: McGraw-Hill.

Daim, T. U., \& Kocaoglu, D. F. (2008). Exploring technology acquisition in Oregon, Turkey and in the U.S. electronics manufacturing companies. The Journal of High Technology Management Research, 19(1), 45-58. http://dx.doi.org/10.1016/j.hitech.2008.06.007

Day, G. S. (1994a). Continuous learning about markets. California Management Review, Summer, 36, 9-31.

Day, G. S. (1994b). The capabilities of market-driven organizations. Journal of Marketing, October, 58, 37-52.

Delaney, J. T., \& Huselid, M. A. (1996). The impact of human resource management practices on perceptions of organizational performance. Academy of Management Journal, 39(4), 949-969. http://dx.doi.org/10.2307/256718

Demirbag, M., Tatoglu, E., Tekinkus, M., \& Zaim, S. (2006). An analysis of the relationship between TQM implementation and organizational performance: Evidence from Turkish SMEs. Journal of Manufacturing Technology Management, 17(6), 829-847. http://dx.doi.org/10.1108/17410380610678828

Douglas, T. J., \& Judge, W. M. (2001). Total quality management implementation and competitive advantage: The role of structural control and exploration. Academy of Management Journal, 44(1), 158-169. http://dx.doi.org/10.2307/3069343

Fitzgerald, L., Johnston, R., Brignall, T. J., Silvestro, R., \& Voss, C. (1991). Performance measurement in service businesses. London: The Chartered Institute of Management Accountants.

Fornell, C. (1992). A national customer satisfaction barometer. Journal of Marketing, 55, 6-21. http://dx.doi.org/10.2307/1252129

Fornell, C., \& Larcker, D. F. (1981). Evaluating structural equation models with unobservable variables and measurement error. Journal of Marketing Research, 18, 39-50. http://dx.doi.org/10.2307/3151312

Fotopoulos, C. V., \& Psomas, E. L. (2010). The structural relationships between TQM factors and organizational performance. The TQM Journal, 22(5), 539-552. http://dx.doi.org/10.1108/17542731011072874

Garengo, P., Biazzo, S., \& Bititci, U. S. (2005). Performance measurement systems in SMEs: A review for a research agenda. International Journal of Management Reviews, 7(1), 25-47. http://dx.doi.org/10.1111/j.1468-2370.2005.00105.x

Glazer, R. (1991). Marketing in an information-intensive environment: Strategic implications 
of knowledge as an asset. Journal of Marketing, October, 55, 1-19.

Griffith, D. A., \& Lusch, R. F. (2007). Getting marketers to invest in firm-specific capital. Journal of Marketing, 71(1), 129-145. http://dx.doi.org/10.1509/jmkg.71.1.129

Gumbus, A., \& Lyons, B. (2002). The Balanced Scorecard at Philips Electronics. Strategic Finance, 84(5), 45-49.

Hair, J. F., Black, W. C., Babin, B. J., Anderson, R. E., \& Tatham, R. L. (2006). Multivariate data analysis. ( $6^{\text {th }}$ ed.). Upper Saddle River, NJ: Pearson Education International.

Harmon, P. (2003). Business process change: A manager's guide to improving, redesigning, and automating processes. San Francisco: Morgan Kaufmann Publishers.

Hayes, R. H., \& Abernathy, W. J. (1980). Managing our way to economic decline. Harvard Business Review, July-August, 67-77.

Hendricks, K. B., \& Singhal, V. R. (1997). Does implementing an effective TQM program actually improve operating performance? Empirical evidence from firms that have won quality awards. Management Science, 43(9), 1258-1274. http://dx.doi.org/10.1287/mnsc.43.9.1258

Hendricks, K., Menor, L., \& Wiedman, C. (2004). The Balanced Scorecard: To adopt or not to adopt? Ivey Business Journal, 69(2), 1-6.

Heskett, J. L., Jones, T. O., Loveman, G. W., Sasser, W. E. Jr., \& Schlesinger, L. A. (1994). Putting the service-profit chain to work. Harvard Business Review, March/April, 164-174.

Holcomb, M. C. (1994). Customer service measurement: A methodology for increasing customer value through utilization of the Taguchi strategy. Journal of Business Logistics, 15(1), 29-52.

Hong, J. J., Chin, A., \& Liu, B. L. (2004). Firm-specific characteristics and logistics outsourcing by Chinese manufacturers. Asia Pacific Journal of Marketing and Logistics, 16(3), 23-36. http://dx.doi.org/10.1108/13555850410765212

Hung, R. Y. Y., Lien, B. Y. H., Yang, B., Wu, C. M., \& Kuo, Y. M. (2010). Impact of TQM and organizational learning on innovation performance in the high-tech industry. International Business Review, 20(2), 213-225. http://dx.doi.org/10.1016/j.ibusrev.2010.07.001

Ittner, C. D., \& Larcker, D. F. (1996). Measuring the impact of quality initiatives on firm financial performance. In Advances in the Management of Organizational Quality, 1, 1-37. Greenwich, CT: JAI Press.

Jacob, R., Madu, C. N., \& Tang, C. (2004). Quality and reliability corner: An empirical assessment of the financial performance of Malcolm Baldrige Award winners. International Journal of Quality and Reliability Management, 21(8), 897-914. http://dx.doi.org/10.1108/02656710410551764 
Juran, J. M. (1992). Juran on quality by design: The new steps for planning quality into goods and services. New York: Free Press.

Kam, B. H., Tsahuridu, E. E., \& Ding, M. J. (2010). Does human resource management contribute to the development of logistics and supply chain capabilities? An empirical study of logistics service providers in China. Research and Practice in Human Resouce Management, 18(2), 15-34.

Kaplan, R. S., \& Norton, D. P. (1992). The Balanced Scorecard - Measures that drive performance. Harvard Business Review, January - February, 70(1), 71-79.

Kaplan, R. S., \& Norton, D. P. (1996). The Balanced Scorecard: Translating strategy into action. Boston, MA: Harvard Business School Press.

Kaplan, R. S., \& Norton, D. P. (2001). The strategy-focused organisation. Boston, MA: Harvard Business School Press.

Kaplan, R. S., \& Norton, D. P. (2004). Measuring the strategic readiness of intangible assets. Harvard Business Review, 82(2), 52-63.

Kaplan, R. S., \& Norton, D. P. (2004). Strategy-maps: Converting intangible assets into tangible outcomes. Boston, MA: Harvard Business School Press.

Kaplan, R. S., \& Norton, D. P. (2005). The Balanced Scorecard: Measures that drive performance. Harvard Business Review, 83(7), 172-180.

Kaynak, H. (2003). The relationship between total quality management practices and their effects on firm performance. Journal of Operations Management, 21, 405-435. http://dx.doi.org/10.1016/S0272-6963 begin_of_the_skype_highlighting

Keegan, D. P., Eiler, R. G., \& Jones, C. R. (1989). Are your performance measures obsolete? Management Accounting (US), 70(12), 45-50.

Kennerley, M., \& Neely, A. (2000). Performance measurement frameworks - A review. Proceedings of Performance Measurement 2000: Past Present and Future Conference, Robinson College, Cambridge, 19-21 July, 291-298.

Kim, J., \& Mueller, C. W. (1978). Factor analysis: Statistical methods and practical issues. Sage University Paper series on Quantitative Applications in the Social Sciences, series no. 07-14. Beverly Hills, CA: Sage.

Knotts, U. S. Jr., Parrish, L. G. Jr., \& Evans, C. R. (1993). What does the US business community really think about the Baldrige Award? Quality Progress, 49-53.

Koene, B. A. S., Vogelaar, A. L. W., \& Soeters, J. L. (2002). Leadership effects on organizational climate and financial performance: Local leadership effect in chain organizations. The Leadership Quarterly, 13, 193-215. http://dx.doi.org/10.1016/S1048-9843

Kuei, C. H., Madu, C. N., \& Lin, C. (2001). The relationship between supply chain quality management practices and organizational performance. International Journal of Quality and 
Reliability Management, 18(8), 864-872. http://dx.doi.org/10.1108/EUM0000000006031

Kuei, C., Madu, C. N., Lin, C., \& Chow, W. S. (2002). Developing supply chain strategies based on the survey of supply chain quality and technology management. The International Journal of Quality and Reliability Management, 19(7), 889-901. http://dx.doi.org/10.1108/02656710210434793

Kumar, V., Choisne, F., Grosbois, D. d., \& Kumar, U. (2009). Impact of TQM on company's performance. International Journal of Quality and Reliability Management, 26(1), 23-37. http://dx.doi.org/10.1108/02656710910924152

Kumar, V., Smart, P.A., Maddern, H., \& Maull, R.S. (2008). Alternative perspectives on service quality and customer satisfaction: the role of BPM. International Journal of Service Industry Management, 19(2), 176-187. http://dx.doi.org/10.1108/09564230810869720

Lai, K. H., Lau, G., \& Cheng, T. C. E. (2004). Quality management in the logistics industry: An examination and a ten-step approach for quality implementation. Total Quality Management, 15(2), 147-159. http://dx.doi.org/10.1080/1478336032000148992

Langley, J., \& Holcomb, M. C. (1992). Creating logistics customer value. Journal of Business Logistics, 13(2), 1-24.

Latshaw, C., \& Choi, Y. (2002). The Balanced Scorecard and the accountant as a valued strategic partner. Review of Business, 23(1), 27-29.

Lieb, R. C., \& Bentz, B. A. (2005). The use of third-party logistics services by large American manufacturers: The 2004 survey. Transportation Journal, 44(2), 24-33.

Lin, C., Chow, W. S., Madu, C. N., Kuei, C. H., \& Yu, P. P. (2005). A structural equation model of supply chain quality management and organizational performance. International Journal of Production Economics, 96, 355-365. http://dx.doi.org/10.1016/j.ijpe.2004.05.009

Lok, P., Hung, R. Y., Walsh, P., Wang, P., \& Crawford, J. (2005). An integrative framework for measuring the extent to which organizational variables influence the success of process improvement programmes. Journal of Management Studies, 42(7), 1357-1381. http://dx.doi.org/10.1111/j.1467-6486.2005.00547.x

Lynch, R. L., \& Cross, K. F. (1991). Measure up - The essential guide to measuring business performance. London: Mandarin.

Maddern, H., Maull, R., \& Smart, P. A. (2007). Customer satisfaction and service quality in UK financial services. International Journal of Operations and Production Management, 27(9), 999-1019. http://dx.doi.org/10.1108/01443570710775838

Madu, C. N., Kuei, C., \& Jacob, R. A. (1996). An empirical assessment of the influence of quality dimensions on organizational performance. International Journal of Production Research, 34(7), 1943-1962. http://dx.doi.org/10.1080/00207549608905006

McCormack, K., \& Johnson, W. (2000). Business process orientation: Gaming the e-business competitive advantage. Delray Beach, FL: St Lucie Press. 
Mentzer, J. T. (1993). Managing channel relations in the $21^{\text {st }}$ century. Journal of Business Logistics, 14(1), 27-41.

Miller, C. C., \& Cardinal, L. B. (1994). Strategic planning and firm performance: A synthesis of more than two decades of research. Academy of Management Journal, 37, 1649-1665. http://dx.doi.org/10.2307/256804

Millen, R. A., \& Maggard, M. (1997). The change in quality practices in logistics: 1995 versus 1991. Total Quality Management, 8(4), 173-179. http://dx.doi.org/10.1080/0954412979604

Montes, F. J. L., Jover, A. V., \& Fernandez, L. M. M. (2003). Factors affecting the relationship between total quality management and organizational performance. International Journal of Quality and Reliability Management, 20(2), 189-209. http://dx.doi.org/10.1108/02656710310456617

Narver, J. C., \& Slater, S. F. (1990). The effect of a market orientation of business profitability. Journal of Marketing, 54(4), 20-35. http://dx.doi.org/10.2307/1251757

National Institute of Standards and Technology (NIST) (1987). Malcolm Baldrige National Award Criteria. Washington, DC: US Commerce Department.

National Institute of Standards and Technology (NIST) (1995). Malcolm Baldrige National Award Criteria. Washington, DC: US Commerce Department.

National Institute of Standards and Technology (NIST) (2002). S\&P stock study. Washington, DC: US Commerce Department.

Neely, A. (1998). A measuring business performance - why, what, how. London: Profile Books Ltd.

Nilsson, L., Johnson, M. D., \& Gustafsson, A. (2001). The impact of quality practices on customer satisfaction and business results: Product versus service organizations. Journal of Quality Management, 6, 5-27. http://dx.doi.org/10.1016/S1084-8568

Niven, P. R. (2002). Balanced scorecard step by step, maximizing performance and maintaining results. New York: John Wiley \& Sons.

Nunnally, J. C. (1978). Psychometric Theory. ( $2^{\text {nd }}$ ed.). New York: McGraw-Hill.

Nunnally, J. C., \& Bernstein, I. H. (1994). Psychometric Theory. (3 ${ }^{\text {rd }}$ ed.). New York: McGraw-Hill.

Oakland, J. S. (1993). Total quality management: The route to improving performance. $\left(2^{\text {nd }}\right.$ ed.). New Jersey: Nichols Publishing Company.

Olve, N., Petri, C., Roy, J., \& Roy, S. (2004). Twelve years later: Understanding and realizing the value of balanced scorecards. Ivey Business Journal, May/June.

Powell, T. C. (1995). Total quality management as competitive advantage: A review and empirical study. Strategic Management Journal, 16(1), 15-37. 
http://dx.doi.org/10.1002/smj.4250160105

Reed, R., Lemak, D. J., \& Montgomery, J. C. (1996). Beyond process: TQM content and firm performance. Academy of Management Review, 21(1), 173-202. $\underline{\text { http://dx.doi.org/10.2307/258633 }}$

Ruben, B. D. (2004). Pursuing excellence in higher education: Eight fundamental challenges. San Francisco, CA: Jossey-Bass.

Ruben, B. D., Russ, T., Smulowitz, S. M., \& Connaughton, S. L. (2007). Evaluating the impact of organizational self-assessment in higher education: The Malcolm Baldrige/Excellence in Higher Education framework. Leadership and Organization Development Journal, 28(3), 230-250. http://dx.doi.org/10.1108/01437730710739657

Rucci, A. J., Kirn, S. P., \& Quinn, R. T. (1998). The employee-customer-profit chain at Sears. Harvard Business Review, 76(11), 82-97.

Sale, M. L., \& Inman, R. A. (2003). Survey-based comparison of performance and change in performance of firms using traditional manufacturing, JIT and TOC. International Journal of Production Research, 41(4), 829-844. http://dx.doi.org/10.1080/0020754031000065520

Samson, D., \& Terziovski, M. (1999). The relationship between total quality management practices and operational performance. Journal of Operations Management, 17, 393-409. http://dx.doi.org/10.1016/S0272-6963

Sandelowski, M. (2000). Combining qualitative and quantitative sampling, data collection, and analysis techniques in mixed-method studies. Research in Nursing and Health, 23, 246-255. http://dx.doi.org/10.1002/1098-240X(200006)23:3<246::AID-NUR9>3.3.CO;2-8

Sanders, N. R. (2007). An empirical study of the impact of e-business technologies on organizational collaboration and performance. Journal of Operations Management, 25(6), 1332-1347. http://dx.doi.org/10.1016/j.jom.2007.01.008

Sapp, R. W., \& Seiler, R. E. (1981). The relationship between long-range planning and financial performance of US commercial banks. Managerial Planning, 38, 32-36.

Shin, H., Collier, D. A., \& Wilson, D. D. (2000). Supply management orientation and supplier/buyer performance. Journal of Operations Management, 18(3), 317-333. http://dx.doi.org/10.1016/S0272-6963

Siddiqui, J., \& Rahman, Z. (2007). TQM principles’ application on information systems for empirical goals. A study of Indian organizations. The TQM Magazine, 19(1), 76-87. http://dx.doi.org/10.1108/09544780710720853

Sila, I., \& Ebrahimpour, M. (2005). Critical linkages among TQM factors and business results. International Journal of Operations and Production Management, 25(11), 1123-1155. http://dx.doi.org/10.1108/01443570510626925

Sinkula, J. M. (1994). Market information processing and organizational learning. Journal of Marketing, 58, 35-45. http://dx.doi.org/10.2307/1252249 
Sit, W. Y., Ooi, K. B., Lin, B., \& Chong, A. Y. L. (2009). TQM and customer satisfaction in Malaysia’s service sector. Industrial Management and Data Systems, 109(7), 957-975. http://dx.doi.org/10.1108/02635570910982300

Skerlavaj, M., Stemberger, M. I., Skrinjar, R., \& Dimovski, V. (2007). Organizational learning culture - The missing link between business process change and organizational performance. International Journal of Production Economics, 106, 346-367. http://dx.doi.org/10.1016/j.ijpe.2006.07.009

Tangen, S. (2004). Performance measurement: From philosophy to practice. International Journal of Productivity and Performance Management, 53(8), 726-737. http://dx.doi.org/10.1108/17410400410569134

Teece, D. J., Pisano, G., \& Shuen, A. (1997). Dynamic capabilities and strategic management. Strategic Management Journal, 18(7), 509-533. http://dx.doi.org/10.1002/(SICI)1097-0266(199708)18:7<509::AID-SMJ882>3.0.CO;2-Z

Tharenou, P., Donohue, R., \& Cooper, B. (2007). Management research methods. New York: Cambridge University Press.

Tsikriktsis, N., \& Heineke, J. (2004). The impact of process variation on customer dissatisfaction: Evidence from the US domestic airline industry. Decision Sciences, 35(1), 129-142. http://dx.doi.org/10.1111/j.1540-5414.2004.02483.x

US General Accounting Office (1991). Management practices: US companies improve performance through quality efforts. Washington, DC: US Printing Office.

Vaidyanathan, G. (2005). A framework for evaluating third party logistics. Communications of the ACM, 48(1), 89-94. http://dx.doi.org/10.1145/1039539.1039544

Van Der Wiele, T., Brown, A., Millen, R., \& Whelan, D. (2000). Improvement in organizational performance and self assessment practices by selected American firms. Quality Management Journal, 7(4), 8-22.

Venkatraman, N., \& Ramanujam, V. (1986). Measurement of business performance in strategy research: A comparison of approaches. Academy of Management Review, 11(4), 801-814. http://dx.doi.org/10.5465/AMR.1986.4283976

Voss, C., Tsikriktsis, N., Funk, B., Yarrow, D., \& Owen, J. (2004b). Managerial choice and performance in service management - a comparison of private sector organizations with further education colleges. London Business School OTM Working Paper No. 04-020, date 2004-06-01.

Wageman, R. (1995). Interdependence and group effectiveness. Administrative Science Quarterly, Vol.40. http://dx.doi.org/10.2307/2393703

Walsh, P. K., Lok, P., \& Jones, M. (2006). The measurement and management of strategic change - A guide to enterprise performance management. Frenchs Forest, NSW: Pearson. 


\section{Macrothink}

Journal of Management Research

ISSN 1941-899X 2012, Vol. 4, No. 1: E15

Wang, P., Wee, C. H., \& Koh, P. H. (1998). Control mechanisms, key personnel appointment, control and performance of Sino-Singaporean joint ventures. International Business Review, 4, 351-375. http://dx.doi.org/10.1016/S0969-5931

Wang, Q., Zantow, K., Lai, F., \& Wang, X. (2006). Strategic postures of third-party logistics providers in Mainland China. International Journal of Physical Distribution and Logistics Management, 36(10), 793-819. http://dx.doi.org/10.1108/09600030610714607

Whitehead, D. D., \& Gupp, B. E. (1985). Bank and thrift profitability: Does strategic planning really pay? Economic Review, 70, 14-25.

Wilson, D. D., \& Collier, D. A. (2000). An empirical investigation of the Malcolm Baldrige National Quality Award causal model. Decision Sciences, 31(2), 361-390. http://dx.doi.org/10.1111/j.1540-5915.2000.tb01627.x

Wood, D. R., \& LaForge, R. L. (1979). The impact of comprehensive planning on financial performance. Academy of Management Journal, 22, 516-526.

http://dx.doi.org/10.2307/255741

Wright, P. M., McMahan, G. C., \& McWilliams, A. (1994). Human resources and sustained competitive advantage: A resource-based perspective. International Journal of Human Resources Management, 5, 301-326. http://dx.doi.org/10.1080/09585199400000020

Yang, C. C. (2006). The impact of human resource management practices on the implementation of total quality management. The TQM Magazine, 18(2), 162-173. http://dx.doi.org/10.1108/09544780610647874

Zack, M. H. (2005). The strategic advantage of knowledge and learning. International Journal of Intellectual Capital and Learning, 2(1), 1-20. http://dx.doi.org/10.1504/IJLIC.2005.006803

\section{Copyright Disclaimer}

Copyright reserved by the author(s).

This article is an open-access article distributed under the terms and conditions of the Creative Commons Attribution license (http://creativecommons.org/licenses/by/3.0/). 